\title{
Permanent and transient congenital hypothyroidism in Korea: analysis of patients in a single center
}

\author{
Jeongho Lee*, Dong Hwan Lee
}

From 8th APPES Biennial Scientific Meeting

Darwin, Australia. 29 October - 1 November 2014

\section{Background}

Congenital hypothyroidism $(\mathrm{CH})$ is one of the most common preventable causes of mental retardation. Neonatal screening programs allow for the early detection and treatment of $\mathrm{CH}$. Transient $\mathrm{CH}$ reverts later to normal, which may or may not require replacement therapy. The aim of this study was to determine the prevalence and manifestations of permanent and transient $\mathrm{CH}$ in Korea.

\section{Methods}

We retrospectively reviewed 610 patients who were diagnosed with $\mathrm{CH}$ from January 2001 to January 2011 in Soonchunhyang University Hospital. They all underwent clinical re-evaluation after the age of 2-3, based on the thyroid function testing after levothyroxine therapy withdrawl.

\section{Results}

Of the 610 patients diagnosed primarily with $\mathrm{CH} ; 554$ (89.1\%) patients were diagnosed to have permanent $\mathrm{CH}$, and $66(10.8 \%)$ patients were diagnosed to have transient $\mathrm{CH}$. The median TSH levels before treatment were significantly higher in patients with permanent $\mathrm{CH}$ than transient $\mathrm{CH}$ (median 58.1:24.1 $\mu \mathrm{IU} / \mathrm{mL}$ ). Male to female ratio was 1:1.2 (35:31) in transient $\mathrm{CH}$. Of the 66 children diagnosed with transient $\mathrm{CH}$, children discontinued levothyroxine replacement therapy at the age of $25.1 \pm 13.2$ months. These patients received relatively low dose hormone replacement (initial and at the time of trial of discontinuation).

\section{Conclusion}

We concluded that the incidence of $\mathrm{CH}$ as well as the transient form similar to the worldwide reported ones.

Department of Pediatrics, Soonchunhyang University Hospital, Seoul, Korea
Published: 28 April 2015

\section{doi:10.1186/1687-9856-2015-S1-P99 \\ Cite this article as: Lee and Lee: Permanent and transient congenital hypothyroidism in Korea: analysis of patients in a single center.} International Journal of Pediatric Endocrinology 2015 2015(Suppl 1):P99.
Submit your next manuscript to BioMed Central and take full advantage of:

- Convenient online submission

- Thorough peer review

- No space constraints or color figure charges

- Immediate publication on acceptance

- Inclusion in PubMed, CAS, Scopus and Google Scholar

- Research which is freely available for redistribution 